\title{
A NEW RECENT MARINE OSTRACODA SPECIES (HEMICYTHERIDAE) FROM BRAZIL
}

\author{
João Carlos Coimbra ${ }^{1}$ \\ Cristianini Trescastro Bergue ${ }^{1}$
}

\begin{abstract}
Ostracods were collected on Sargassum sp. from the littoral of São Sebastião, São Paulo State, southeastern Brazil. A new species, Aurila ornellasae, is illustrated and described based on a population with various instars and adult specimens. This is the first living species of this genus described from Brazil. A brief discussion on the systematics of the genus Aurila Pokorný, 1955 and its allied genera is presented.
\end{abstract}

KEYWORDS. Hemicytherinae, Aurila, Sargassum, São Paulo, littoral.

\section{INTRODUCTION}

Although Aurila Pokorný, 1955 presents numerous living and fossil species around the world, it remained very problematical taxonomically for a long time, due to the difficulty to establish diagnostic characters that permit the clear distinction of this taxon and closed taxa such as Mutilus Neviani, 1928. JellineK (1995) presented a study on the problem firstly pointed out by BoNADUCE et al. (1987) on the living socalled Mutilus and allied genera. He included the description of two new genera, Auradilus Jellinek, 1995 and Tepidiora Jellinek, 1995 and a table with morphological differences among some allied hemicytherid genera. In this table, Aurila s. $l$. and Mutilus are described with the following central muscle scar pattern: 1-2-1-1 adductors +3 frontal scars. In respect to the ornamentation, only Mutilus presents a typical butterfly-shape in the central area of the valves. All species of this last genus are restricted to the Mediterranean fossil record (JELLINEK, 1995).

HARRISON et al. (2000), based upon carapace morphology, separated into seven species groups forty-one Pliocene species/subspecies of Aurila in North West France. In this paper there is a taxonomic history of the genus Aurila, and discussions on the morphological differences between Mutilus and Aurila, as well as between Aurila and other less similar genera as Urocythereis Ruggieri, 1950 and Patrizia

1. Universidade Federal do Rio Grande do Sul, Instituto de Geociências, Depto. de Paleontologia e Estratigrafia, Caixa Postal 15001, 91501-970, Porto Alegre, RS, Brasil. (joao.coimbra@ufrgs.br) 
Bonaduce \& Russo, 1990. Harrison et al. (2000) proposed that "Mutilus is characterized by their robust, heavily ornate, thick shells with strongly developed ribs or reticulae, e.g., Mutilus splendidornatus Hartmann, 1974". The present authors do not regard this species as Mutilus because, according to Jelliner (1995), it presents morphological characteristics of Auradilus, such as: posterodorsal shoulder, central muscle scar pattern 1-2-2-1 adductors +3 frontal scars, and the absence of the butterfly-shape in the central area of the valves.

The emended diagnosis of the genus Aurila given by HARrison et al. (2000) fits very well with the new species here described from Brazil. This species has the typical ear-shaped LV in lateral view with strongly reticulate ornament, that characterize the Aurila species group 1 of HARRISON et al. (2000). This is the first living species of this genus described from Brazilian waters. The studied specimens were collected on Sargassum sp. from the littoral of São Sebastião, São Paulo State, southeastern Brazil. The ostracodefauna comprises three species: Loxoconcha bullata Hartmann, 1956, Sclerochilus sp. and Aurila ornellasae sp. nov. Different of Sclerochilus sp., that presents few specimens, A. ornellasae sp. nov. is illustrated and described based on a population with various instars and adult specimens.

The analysis of 766 samples collected by various oceanographical projects (Remac, Geomar III and VI, El Austral, and Revizee-South Score), along the continental shelf of Brazil, has revealed the absence of $A$. ornellasae sp. nov. on the continental shelf. An analysis of one sandy sample from Guanabara Bay (Rio de Janeiro) showed the presence of few empty valves and living specimens of this new species.

\section{MATERIAL AND METHODS}

Samples were collected on Sargassum sp., also known as gulfweed, which grows well in the tropics. The nine samples studied came from the littoral of São Sebastião, São Paulo State, southeastern Brazil (fig. 1). To collect Ostracoda on Sargassum sp., some bunches were covered with a plastic bag, and cut off from the plant. The material was washed through a $250 \mathrm{mesh} / \mathrm{inch}$ sieve and dried. All specimens were picked up under the microscope.

The type-material is held in the Museu de Paleontologia, Universidade Federal do Rio Grande do Sul, Porto Alegre, Seção de Ostracoda (MP-O). The following abbreviations are employed in the species description: LV, left valve; RV, right valve; L, length; h, height; w, width.

\section{HEMICYTHERINAE}

\section{Aurila ornellasae sp. nov.}

(Figs. 2-6)

Aurila sp. Whatley et al., 1998:103, pl. 3, figs. 20, 21 from Alcatrazes Island, São Paulo (non Aurila sp. Whatley et al., 1997:38, pl. 6, fig. 17 from southeastern Argentina).

Etymology. In honour to Dr. Lilia Pinto de Ornellas by her important studies on marine ostracods from Brazil.

Type material. BRAZIL, São Paulo, São Sebastião beach (on Sargassum sp.), $23^{\circ} 48^{\prime}$ S $45^{\circ} 25^{\prime} \mathrm{W}$ : holotype , , MP-O 1756, LV, L $0.62 \mathrm{~mm}, \mathrm{~h} 0.40 \mathrm{~mm}$; paratypes: + , MP-O 1755, RV, L $0.61 \mathrm{~mm}$, h $0.37 \mathrm{~mm}$; , MP-O 1757 , L $0.63 \mathrm{~mm}$, w $0.32 \mathrm{~mm}$; ơ, MP-O 1758, L $0.64 \mathrm{~mm}$, w $0.29 \mathrm{~mm}$; juvenile, MP-O-1759, RV, L $0.51 \mathrm{~mm}$, h $0.29 \mathrm{~mm}$. 


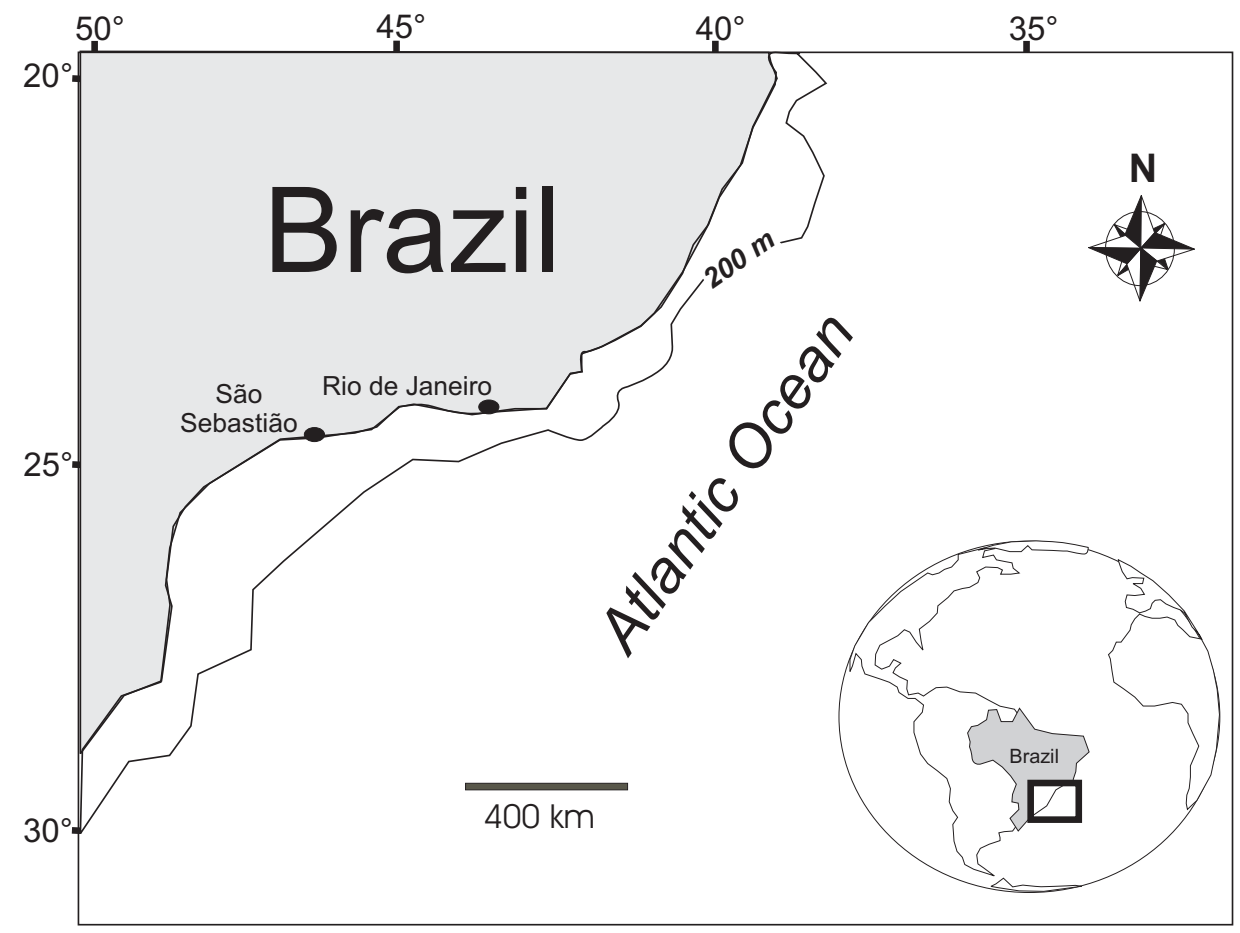

Fig. 1. São Sebastião, located in the northern coast of São Paulo State, Brazil.

Additional material examined. Brazil, Rio de Janeiro, Guanabara bay. Eleven carapaces and six valves.

Diagnosis. Dimorphic species, medium size carapace, with heavy reticulate ornament concentrically disposed. Solum of each reticulum presents a little developed second-order reticulation. Towards the centre of both valves the reticulae are smaller and more rounded.

Description (figs. 2-6). Medium carapace, heavily calcified, typically auriculate shape. LV ear-like in lateral view, with dorsal margin very rounded and little developed posterior cardinal angle. RV subrectangular, with dorsal outline slightly sloping to the posterior end and conspicuous cardinal angles. Ventral margin with marked oral concavity more visible in RV. Maximum median height in LV, and at about one third from the front in RV; maximum width in the mid-length. Caudal process better developed and upturned in RV. Surface coarsely and concentrically reticulate. Towards the centre of both valves, reticulae smaller and more rounded, becoming larger and diffuse near margins. They vary in shape from circular to subovate and elongate, always with little developed second-order reticulation. Eye tubercle subperipheral, large and glassy. Opaque patches not visible. Valves convex medially in dorsal view. 


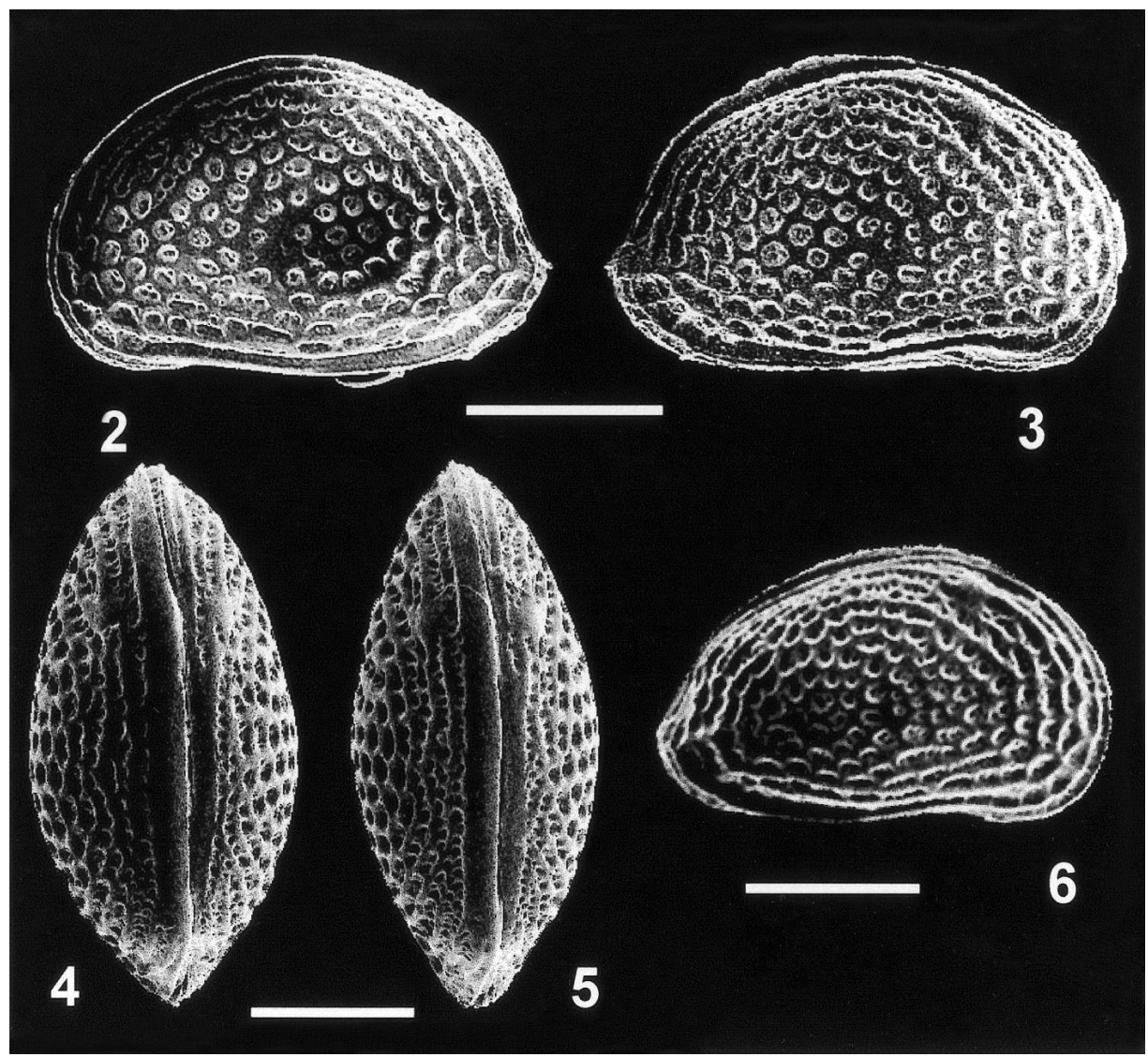

Figs. 2-6. Aurila ornellasae sp. nov.: 2, holotype + , LV (MP-O 1756); 3, paratype $q$, RV (MP-O 1755); 4, paratype + , C, dorsal view (MP-O 1757); 5, paratype $\sigma^{7}, \mathrm{C}$, dorsal view (MP-O 1758); 6, paratype, juvenile, RV (MP-O 1759). Scales, $200 \mathrm{~mm}$.

Internal view: muscle scar pattern typical of the genus, with three frontal scars and four adductor scars, the dorso-median is divided in two. Hinge with the frontal element strongly developed. Radial pore canals numerous, closely spaced from about mid-height on anterior margin towards oral region. One or two canals extend dorsally to the caudal process. Vestibulum very little developed in the anterior end.

Remarks. Whatley et al. (1998) refer two specimens from sediments of Alcatrazes Island (São Paulo State, Brazil) as co-specifics to Aurila sp., a species firstly determined by Whatley et al. (1997) from Puerto Madryn Playa, Argentina, $42^{\circ} 50^{\prime} \mathrm{S}$. Aurila ornellasae is different of the Argentinean species; its shape and ornaments fit much well with the specimens from the Alcatrazes Island. Aurila sp., registered by WhatLey et al. (1997), is co-specific with a probably new Miocene species, erroneously identified by SANGUINETTI (1979) as Aurila trigonula (Jones, 1856) from Pelotas basin, registered as the oldest Aurilini species from Brazil. Aurila 
trigonula was originally described from the Pliocene of England, and has occurrences in European basins and in the Miocene of Trinidad (BolD, 1957). A comparative analysis between the Sanguinetti's and European and Trinidad specimens, has demonstrated that they are distinct species.

Aurila ornellasae resembles $A$. convexa (Baird, 1850), but it differs in the LV dorsal margin of $A$. convexa that slopes gently backwards, whereas in A. ornellasae the cardinal angles are more defined; the ventral margin of both valves of the Baird species is obscured by a small ventro lateral inflation absent in the new species; the ornamentation is more conspicuous and the caudal process weaker in A. ornellasae.

Distribution. São Sebastião beach, São Paulo State; sandy sediments at Guanabara Bay, Rio de Janeiro State; and bottom sediments of Alcatrazes Island (25 $m$ in depth), São Paulo State.

Ecology. The ostracods on Sargassum sp. from São Sebastião beach are represented by Loxoconcha bullata Hartmann, 1956, Sclerochilus sp., and Aurila ornellasae. An additional analysis of hundreds of samples, collected along the Brazilian continental shelf, has revealed the absence of $A$. ornellasae. Thus, it is possible to hypothesize that $A$. ornellasae is restricted to littoral environments.

Acknowledgments. To Dr. Gerson Fauth (UNISC-RS) for his comments, criticism, advice, and for the improvement of this paper. To CNPq (grant 520309/99-5), which enabled the senior author to participate in this study.

\section{REFERENCES}

Bold, W. A. van den 1957. Oligo-Miocene Ostracoda from southern Trinidad Micropaleont., New York, 3(3):231-254.

Bonaduce, G.; Ruggieri, G. \& Russo, A. 1987. The ostracod genus Mutilus and so-called Mutilus from the Mediterranean Miocene-Pleistocene. Boll. Soc. Paleont. Ital., Modena, 26(3):251268.

Harrison, D.; Maybury, C. \& Whatley, R.C. 2000. The ostracod genus Aurila from the Pliocene of north west France. Revta Esp. Micropaleont., Madrid, 32(1):21-60.

Jellineck, T. 1995. The Plio-Pleistocene genus Mutilus Neviani 1955 (Ostracoda) and some of its so-called Recent descendants. Senckenberg. lethaea, Frankfurt, 75:163-191.

Sanguinetti, Y. T. 1979. Miocene ostracodes of the Pelotas basin, State of Rio Grande do Sul, Brazil. Pesquisas, Porto Alegre, 12:119-187.

Whatley, R. C.; Moguilevsky, A.; Chadwick, J. et al. 1997. Ostracoda from the South West Atlantic. Part II. The littoral fauna from between Tierra del Fuego and the Río de La Plata.

Revta Esp. Micropaleont., Madrid, 29(2):5-83.

Whatley, R. C.; Moguilevsky, A.; Toy, N. et al. 1998. Ostracoda from the South West Atlantic. Part III. Recent Ostracoda from the continental shelf of Argentina, Uruguay and southern Brazil. Revta Esp. Micropaleont., Madrid, 30(2):89-116. 